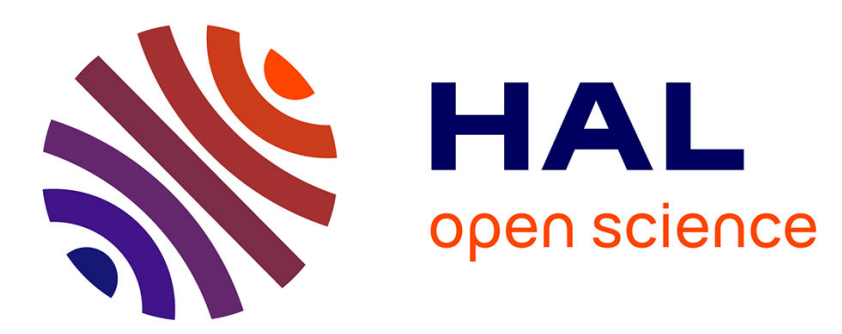

\title{
Two amide glycosides from Portulaca oleracea L. and its bioactivities
}

Xilong Liu, Haibo Wu, Xiaojun Tao, Xixiang Ying, Didier Stien

\section{To cite this version:}

Xilong Liu, Haibo Wu, Xiaojun Tao, Xixiang Ying, Didier Stien. Two amide glycosides from Portulaca oleracea L. and its bioactivities. Natural Product Research, 2021, 35, pp.2655-2659. 10.1080/14786419.2019.1660333 . hal-02331754

\section{HAL Id: hal-02331754 \\ https://hal.science/hal-02331754}

Submitted on 24 Oct 2019

HAL is a multi-disciplinary open access archive for the deposit and dissemination of scientific research documents, whether they are published or not. The documents may come from teaching and research institutions in France or abroad, or from public or private research centers.
L'archive ouverte pluridisciplinaire HAL, est destinée au dépôt et à la diffusion de documents scientifiques de niveau recherche, publiés ou non, émanant des établissements d'enseignement et de recherche français ou étrangers, des laboratoires publics ou privés. 


\section{Two amide glycosides from Portulaca oleracea L. and its bioactivities}

Xilong Liu ${ }^{\text {a† }}$, Haibo $\mathrm{Wu}^{\mathrm{b \dagger}}$, Xiaojun Tao ${ }^{\mathrm{a}}$, Xixiang Ying ${ }^{\mathrm{a},{ }^{*}}$ and Didier Stien ${ }^{\mathrm{c},{ }^{,}}$

\section{Affiliation}

${ }^{a}$ School of Pharmacy, Liaoning University of Traditional Chinese Medicine, Dalian, P.R. China

${ }^{b}$ Cancer Intervention Department, Shenyang Sujiatun District Central Hospital, Shenyang, P.R. China

${ }^{\mathrm{c}}$ Sorbonne Université, CNRS, Laboratoire de Biodiversité et Biotechnologie Microbienne

E-mail address in order:

liuxilong31518@163.com,yingxixiang@hotmail.com, taoxjun@foxmail.com , yingxixiang@163.com and didier.stien@cnrs.fr

\section{${ }^{*}$ Correspondence}

Correspondence: Prof. Xixiang Ying, School of Pharmacy, Liaoning University of Traditional Chinese Medicine, No.77, Shengming 1 Road, DD Port, Dalian, 116600, P.R. China, Tel: +86-0411-85890139, Fax: +86-0411-85890128, yingxixiang@163.com

Co-correspondence: Prof. Didier Stien, Sorbonne Université, CNRS, Laboratoire de Biodiversité et Biotechnologie Microbienne, USR3579, Observatoire Océanologique, 66650, Banyuls-sur-mer, France, Tel: +33-430192476, didier.stien@cnrs.fr 
${ }^{\dagger}$ Xilong Liu and Haibo Wu contributed equally to this work.

\section{Abstract}

Two novel amide glycosides, named oleraciamide $E(\mathbf{1})$ and oleraciamide $F(2)$, were isolated from the Portulaca oleracea L. Their structures were determined by means of 1D and 2D NMR spectroscopic and UHPLC-ESI-TOF-MS methods. Oleraciamide E (1) exhibited anticholinesterase activity with IC50 values of $52.43 \pm 0.33 \mu \mathrm{M}$, and presented scavenging activity in 1,1-diphenyl-2-picrylhydrazyl (DPPH) radical quenching assay with the $\mathrm{IC}_{50}$ values of $24.64 \pm 0.33 \mu \mathrm{M}$.

Keywords: Portulaca oleracea L.; amide glycosides; anticholinesterase activity; antioxidant activity 


\section{Introduction}

Portulaca oleracea $\mathrm{L}$. is an annual succulent herb belonging to a member of the Portulacaceae family, which is widely distributed in different geographical environments all over the world (Zheng et al. 2018). In China, P. oleracea L. has been used as a traditional Chinese medicine (TCM) for thousands of years (Lei et al. 2015) because it exhibits many pharmacological effects, such as anti-inflammatory (Meng et al. 2016), antibacterial (Chan et al. 2015), anticholinesterase (Xiu et al. 2018), antioxidant (Lim et al. 2007), antitumor (Shen et al. 2013), neuroprotective (Sumathi et al. 2016), and so on. Therefore, more and more scholars paid more attention on its therapeutic substances, until now, many active ingredients have been isolated from the plants, for instance, alkaloids (Jiao et al. 2015, Li et al. 2016, Li et al. 2017, Xu et al. 2017, Jiang et al. 2018, Zhao et al. 2018, Zhao et al. 2019, Ma et al. 2019), flavonoids (Yang et al. 2018, Yang et al. 2018), organic acids (Wang et al. 2017), terpenoids (Xin et al. 2008), lignans (Ma et al. 2018), etc. This study is aim to isolate the bioactive substance from $P$. oleracea $\mathrm{L}$. and investigate their activities. As a result, two novel amide glycosides named oleraciamide $E(\mathbf{1})$ and oleraciamide $F$ (2), shown in Figure 1, were isolated from the P. oleracea L., furthermore, the antioxidant and anticholinesterase activities of oleraciamide E (1) were studied.

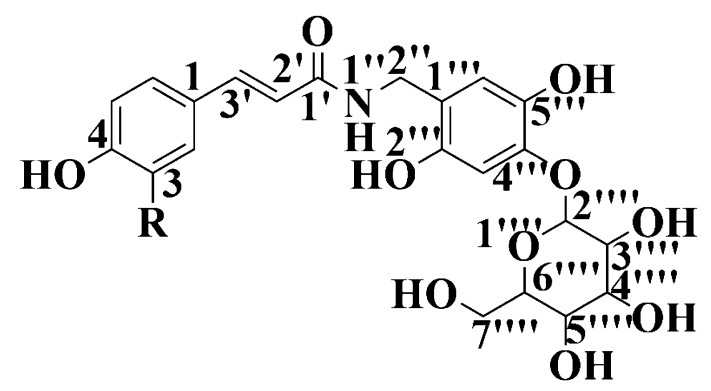

Figure 1. Structure of compounds 1 and 2. 


\section{Results and discussion}

Compound 1 was obtained as yellow green powder turned orange when sprayed Dragendorff's reagent. UV (MeOH) $\lambda_{\max } 310 \mathrm{~nm}$. IR (KBr) $v_{\max } 3382,3256,2920$, 2849, 1607, 1514, 1490,1443, 1389, 1175, 1028, 998, 831 and $773 \mathrm{~cm}^{-1}$. The molecular formula of compound 1 was identified as $\mathrm{C}_{22} \mathrm{H}_{25} \mathrm{NO}_{10}$ with 11 degrees of unsaturation, which was deduced from the NMR data (Table S1, in supplementary material) and UHPLC-ESI-TOF-MS at $\mathrm{m} / z$ 464.1547 [M+H] ${ }^{+}$(calcd 464.1552). According to the ${ }^{13} \mathrm{C}$ NMR, the DEPT 135 and the HSQC spectra, Compound 1 possesses 22 carbon signals, including 2 methylenes $\left(\delta_{C} 33.5,62.6\right), 13$ methines including 5 aliphatic carbons $\left(\delta_{C} 69.2,73.5,76.0,77.0,104.2\right)$ and 8 olefinic carbons $\left(\delta_{C} 108.6,111.7,115.7,118.0,129.4,139.9\right.$, in which 115.7 and 129.4 were overlapped), 7 quaternary carbons, including 1 carbonyl carbon $\left(\delta_{C} 163.9\right)$ and 6 olefinic carbons $\left(\delta_{C} 126.1,126.2,136.1,143.2,143.6,159.1\right)$. The ${ }^{1} H$ NMR $(600$ MHz, DMSO- $\left.d_{6}\right)$ and ${ }^{13} \mathrm{C}$ NMR $\left(150 \mathrm{MHz}\right.$, DMSO- $\left.d_{6}\right)$ data are listed in (Table S1, in supplementary material). An AA'BB' spin was established by the hydrogen signals at $\delta_{\mathrm{H}} 6.78(2 \mathrm{H}, \mathrm{d}, \mathrm{J}=8.28 \mathrm{~Hz}), \delta_{\mathrm{H}} 7.41(2 \mathrm{H}, \mathrm{d}, \mathrm{J}=9.36 \mathrm{~Hz})$ and the carbon signals at $\delta_{\mathrm{C}}$ 115.7 (C-3 and C-5, overlapped), $\delta_{C} 129.4$ (C-2 and C-6, overlapped). The ${ }^{13} \mathrm{C}$ NMR signal C-4 $\left(\delta_{C} 159.1\right)$ locates at low field area indicated that C-4 connected with a hydroxyl. The HMBC correlations from $\mathrm{H}-3^{\prime}$ to $\mathrm{C}-2, \mathrm{C}-6$, and from $\mathrm{H}-2$ ' to $\mathrm{C}-1$, and from $\mathrm{H}-3, \mathrm{H}-5$ to $\mathrm{C}-1$, revealed direct connection of $\mathrm{H}-3^{\prime}$ with $\mathrm{C}-1$. The ${ }^{1} \mathrm{H}$ NMR signal indicated that $\mathrm{H}-2^{\prime}\left(\delta_{H} 6.68,1 \mathrm{H}, \mathrm{d}, \mathrm{J}=15.24 \mathrm{~Hz}\right), \mathrm{H}-3^{\prime}\left(\delta_{\mathrm{H}} 7.39,1 \mathrm{H}, \mathrm{d}, \mathrm{J}=15.50 \mathrm{~Hz}\right)$ belonged to trans double bond. The HMBC correlations from $\mathrm{H}-2$ ', $\mathrm{H}-3^{\prime}$ to the 
carbonyl at $\mathrm{C}-1^{\prime}\left(\delta_{\mathrm{C}} 163.9\right)$ indicated that the double bond linked to the amide carbonyl ( $\delta \mathrm{C} 163.9)$. The HMBC correlations from $\mathrm{H}-2$ ' to $\mathrm{C}-2$ " indicated that C-2" linked to the amide group. The signals at $H-3^{\prime \prime \prime}\left(1 \mathrm{H}, \mathrm{s}, \delta_{H} 8.12\right), \mathrm{H}-6^{\prime \prime \prime}\left(1 \mathrm{H}, \mathrm{s}, \delta_{H}\right.$ 6.64) are typical of a tetrasubstituted aromatic ring. The ${ }^{13} \mathrm{C}$ NMR signal C-2"' $\left(\delta_{C}\right.$ 143.6), C-5"' ( $\delta_{C}$ 143.2) at low field area indicated that C-2"', $C-5$ "' linked to hydroxyl. The HMBC correlations from H-6"' to C-2" and from H-2" to C-2"', and from H-2" to C1"', indicated that C-2" linked to C-1"'. The HMBC correlations from $\mathrm{H}-2$ "'"' to the carbon at C-4"' ( $\left.\delta_{c} 104.2\right)$, the NOESY correlations from $\mathrm{H}-2^{\prime \prime \prime \prime}$ to $\mathrm{H}-3^{\prime \prime \prime}$ and the

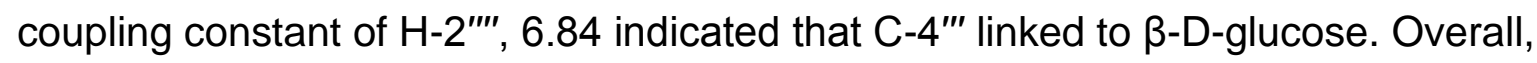
compound 1 was identified as the $(E)-N-(2,5-$ dihydroxy-4-((3,4,5-trihydroxy-6(hydroxymethyl)tetrahydro-2H-pyran-2- yl)oxy)benzyl)-3-(4hydroxyphenyl)acrylamide, named oleraciamide E (1) (Experimental section, in supplementary material).

Compound 2 was obtained as yellow green powder turned orange when sprayed Dragendorff's reagent. its molecular formula was identified as $\mathrm{C}_{23} \mathrm{H}_{27} \mathrm{NO}_{11}$ with 11 degrees of unsaturation only by comparing the ${ }^{1} \mathrm{H}-{ }^{1} \mathrm{H}$ COSY and ROESY data with compound 1 due to its low content (Table S2, in supplementary material), additionally, it was deduced from the UHPLC-ESI-TOF-MS at $m / z 314.1024$ [M$\left.\mathrm{C}_{6} \mathrm{H}_{12} \mathrm{O}_{6}+\mathrm{H}\right]^{+}$(calcd 314.1023) (Figure S21, in supplementary material). Compared the ${ }^{1} \mathrm{H}$ NMR and ${ }^{1} \mathrm{H}-1 \mathrm{H}$ COSY signal with compound $1, \mathrm{H}-2^{\prime}\left(\delta_{H} 6.73,1 \mathrm{H}, \mathrm{d}, \mathrm{J}=15\right.$ $\mathrm{Hz}), \mathrm{H}-3^{\prime}\left(\delta_{H} 7.39,1 \mathrm{H}, \mathrm{d}, \mathrm{J}=15 \mathrm{~Hz}\right)$ belonged to trans double bond of the compound 2, and the $H-2\left(1 \mathrm{H}, \mathrm{s}, \delta_{H} 7.16\right), \mathrm{H}-5\left(1 \mathrm{H}, \mathrm{d}, \delta_{\mathrm{H}}\right.$ 7.02) and $\mathrm{H}-6\left(1 \mathrm{H}, \mathrm{d}, \delta_{\mathrm{H}} 6.79\right)$ were the signals of $1,3,4$-tribstituted aromatic ring. The signals $\delta_{C} 55.0 / \delta_{H} 3.80(3 \mathrm{H}, \mathrm{s})$ are typical of a methoxy group, and a methoxy group can be placed in C-3 based on the 
ROESY correlation of the methyl protons with $\mathrm{H}-2$ also indicated that the compound has a 3-spin system. Taken together, compound 2 was identified as the $(E)-N-(2,5-$ dihydroxy-4-((3,4,5-trihydroxy-6-(hydroxymethyl)tetrahydro-2H-pyran-2yl)oxy)benzyl)-3-(4-hydroxy-3-methoxyphenyl)acrylamide, named oleraciamide F (2) (Experimental section, in supplementary material).

Alzheimer's disease (AD), an irreversible progressive neurodegenerative disorder of the central nervous system (CNS), is characterized by a gradual loss of cognitive ability in the elderly (Jiang et al. 2018). At present, clinical treatment strategies for AD are used mainly to improve cholinergic neurotransmission in the brain, and these treatments are mostly based on the cholinergic hypothesis (Hu et al. 2019). Acetylcholinesterase $(\mathrm{AChE})$ plays a significant role in the termination of nerve impulse transmission at the cholinergic synapses by rapid hydrolysis of acetylcholine (ACh) (Yang et al. 2012), AChE inhibitors are therefore being the first choice of drugs for the treatment of AD (Kaufmann et al. 2016). In this study, compound 1 exerted an inhibitory activity against the AChE with dose-dependent (Figure S14, in supplementary material) with the $\mathrm{IC}_{50}$ values of $52.43 \pm 0.33 \mu \mathrm{M}$ (Table S3, in supplementary material). The antioxidant activity of the compound $\mathbf{1}$ was performed using the DPPH radical scavenging method (María I. Gil et al. 2000). The results indicated that compound $\mathbf{1}$ presented higher antioxidant activity than that of $\mathrm{BHA}$ (Table S4, in supplementary material) as its phenolic hydroxyl groups played an important role in scavenging DPPH radical (Yang et al. 2009), and the antioxidant activity of compound $\mathbf{1}$ was dose-dependent (Figure S15, in supplementary material).

\section{Conclusion}


In this study, two novel amide glycosides, oleraciamide $\mathrm{E}$ and oleraciamide $\mathrm{F}$ possessing similar structures, were isolated from $P$. oleracea $L$. for the first time, and compound $\mathbf{1}$ presented remarkably anticholinesterase and antioxidant effects.

\section{Supplementary material}

Supporting information can be found in the online version of this article.

\section{Disclosure statement}

The authors have no conflicts of interest to disclose.

\section{Acknowledgements}

This work was supported by the National Natural Science Foundation of China (Grant 81573546).

\section{References}

Chan BC, Han XQ, Lui SL, Wong CW, Wang TB, Cheung DW, Cheng SW, Ip M, Han SQ, Yang XS, et al. 2015. Combating against methicillin-resistant Staphylococcus aureus-two fatty acids from Purslane (Portulaca oleracea L.) exhibit synergistic effects with erythromycin. J Pharm Pharmacol. 67:107-116. 
Hu JH, Huang YD, Pan TT, Zhang TH, Su T, Li XS, Luo HB, Huang L. 2019.

Design, synthesis, and biological evaluation of dual-target inhibitors of

acetylcholinesterase (AChE) and phosphodiesterase 9A (PDE9A) for the treatment of Alzheimer's disease. ACS Chem Neurosci. 10:537-551.

Jiao ZZ, Yue S, Sun HX, Jin TY, Wang HN, Zhu RX, Xiang L. 2015. Indoline amide glucosides from Portulaca oleracea: isolation, structure, and DPPH radical scavenging activity. J Nat Prod. 78:2588-2597.

Jiang MY, Zhang WJ, Yang X, Xiu F, Xu HR, Ying XX, Stien D. 2018. An isoindole alkaloid from Portulaca oleracea L. Nat Prod Res. 32:2431-2436.

Jiang XY, Chen TK, Zhou JT, He SY, Yang HY, Chen Y, Qu W, Feng F, Sun HP. 2018. Dual GSK-3ß/AChE inhibitors as a new strategy for multitargeting anti-Alzheimer's disease drug discovery. ACS Med Chem Lett. 9:171-176.

Kaufmann D, Kaur Dogra A, Tahrani A, Herrmann F, Wink M. 2016. Extracts from Traditional Chinese Medicinal plants inhibit acetylcholinesterase, a known Alzheimer's disease target. Molecules. 21:1161.

Lei X, Li JM, Liu B, Zhang N, Liu HY. 2015. Separation and identification of four new compounds with antibacterial activity from Portulaca oleracea L. Molecules. 20:16375-16387.

Li CY, Meng YH, Ying ZM, Xu N, Hao D, Gao MZ, Zhang WJ, Xu L, Gao YC, Ying 
XX. 2016. Three novel alkaloids from Portulaca oleracea L. and their anti-inflammatory effects. J Agric Food Chem. 64:5837-5844.

Li CY, Ying ZM, Gao MZ, Wei WJ, Hao D, Xu L, Tao XJ, Zhang WJ, Ying XX, Liu J. 2017. Two new similar alkaloids from Portulaca oleracea L. Nat Prod Res. 31:1792-1798.

Lim YY, Quah EPL. 2007. Antioxidant properties of different cultivars of Portulaca oleracea. Food Chemistry. 103:734-740.

Ma YF, Bao YR, Zhang WJ, Ying XX, Stien D. 2018. Four lignans from Portulaca oleracea L. and its antioxidant activities. Nat Prod Res. 1-7.

DOI:10.1080/14786419.2018.1534852.

Ma YF, Li XT, Zhang WJ, Ying XX, Stien D. 2019. A trace alkaloid, oleraisoindole A from Portulaca oleracea L. and its anticholinesterase effect. Nat Prod Res. 1-4. DOI: $10.1080 / 14786419.2019 .1627356$.

Marı'a I. Gil, Francisco A. Toma's-Barbera'n, Betty Hess-Pierce, Deirdre M. Holcroft, Kader. AA. 2000. Antioxidant activity of pomegranate juice and its relationship with phenolic composition and processing. J Agric Food Chem. 48:4581-4589.

Meng YH, Ying ZM, Xiang Z, Hao D, Zhang WJ, Zheng Y, Gao YC, Ying XX. 2016. The anti-inflammation and pharmacokinetics of a novel alkaloid from 
Portulaca oleracea L. J Pharm Pharmacol. 68:397-405.

Shen H, Tang G, Zeng G, Yang YJ, Cai XW, Li DL, Liu HC, Zhou NX. 2013. Purification and characterization of an antitumor polysaccharide from Portulaca oleracea L. Carbohydr Polym. 93:395-400.

Sumathi T, Christinal J. 2016. Neuroprotective effect of Portulaca oleraceae ethanolic extract ameliorates methylmercury induced cognitive dysfunction and oxidative stress in cerebellum and cortex of rat brain. Biol Trace Elem Res. 172:155-165.

Wang HQ, Zhang LY, Wang YY. 2017. Isolating and identifying organic acids from Portulaca oleracea and determining their anti-cyanobacterial activity. Pol J Environ Stud. 26:441-445.

Xiu F, Li XT, Zhang WJ, He F, Ying XX, Stien D. 2018. A new alkaloid from Portulaca oleracea L. and its antiacetylcholinesterase activity. Nat Prod Res. 1-8. DOI: 10.1080/14786419.2018.1460833.

Xin HL, Xu YF, Hou YH, Zhang YN, Yue XQ, Lu JC, Ling CQ. 2008. Two novel triterpenoids from Portulaca oleracea L. Helv Chim Acta. 91:2075-2080.

Xu L, Ying ZM, Wei WJ, Hao D, Wang HB, Zhang WJ, Li CY, Jiang MY, Ying XX, Liu J. 2017. A novel alkaloid from Portulaca oleracea L. Nat Prod Res. 31:902-908. 
Yang X, Ying ZM, Liu HR, Ying XX, Yang GL. 2018. A new homoisoflavone from Portulaca oleracea L. and its antioxidant activity. Nat Prod Res. 1-7. DOI:10.1080/14786419.2018.1484465.

Yang X, Zhang W, Ying X, Stien D. 2018. New flavonoids from Portulaca oleracea L. and their activities. Fitoterapia. 127:257-262.

Yang ZD, Zhang X, Du J, Ma ZJ, Guo F, Li S, Yao XJ. 2012. An aporphine alkaloid from Nelumbo nucifera as an acetylcholinesterase inhibitor and the primary investigation for structure-activity correlations. Nat Prod Res. 26:387-392.

Yang ZJ, Liu CJ, Xiang L, Zheng YN. 2009. Phenolic alkaloids as a new class of antioxidants in Portulaca oleracea. Phytother Res. 23:1032-1035.

Zhao CC, Ying ZM, Tao XJ, Jiang MY, Ying XX, Yang GL. 2017. A new lactam alkaloid from Portulaca oleracea L. and its cytotoxity. Nat Prod Res. 32:1548-1553. Zhao CC, Zhang CG, He F, Zhang WJ, Leng AJ, Ying XX. 2019. Two new alkaloids from Portulaca oleracea L. and their bioactivities. Fitoterapia.

DOI:10.1016/j.fitote.2019.05.005.

Zheng GY, Mo FF, Ling C, Peng H, Gu W, Li M, Chen Z. 2018. Portulaca oleracea L. alleviates liver injury in streptozotocin-induced diabetic mice. Drug Des Devel Ther. 12:47-55. 